\title{
Miscellany
}

\section{Birthday Honours}

In October 1997, Colonel Professor R. R. TilleardCole received the Order of the British Empire.

\section{New psychiatric art Web site}

A Web site for a gallery of pscyhiatric art has been set up by The Cunningham Dax Gallery of Psychiatric Art. Web site address: WWW.PSYCHART.ORG.AU/ ECDAX. Further information: The Cunningham Dax Gallery of Psychiatric Art, 35 Poplar Road, Parkville, Victoria, Australia 3052 (Telephone: 039342 2394).

\section{New publications}

Patients' views have become an increasingly important factor for mental health professionals in their efforts for increased effectiveness in their clinical practice. Children are no exception to this. The multi-professional FOCUS project at the Royal College of Psychiatrists' Research Unit aims to assist this process by producing a series of information sheets along the theme of Involving Children in Decision Making. This series, launched with a discussion document, details current initiatives in this area and an information sheet outlining the resources currently available. It is envisaged that these sheets will be of use not only to mental health professionals, but will serve as a 'starting point' to young people and parents/carers of children suffering from mental health problems who would like to be involved in treatment decisions but are unsure as to how this might be approached. Further information: Carol Joughin, Project Manager, Royal College of Psychiatrists' Research Unit, 11 Grosvenor Crescent, London SW1X 7EE (Telephone: 01712352351 ext. 256).

Age Concern have recently published Drugs and Dementia: A Guide to Good Practice in the Use of Neuroleptic Drugs in Care Homes for Older People. Reassurance and practical information is offered to care home residents, their families and care homes staff concerned about the effects of neuroleptics. It outlines good practice for care managers, care staff, GPs, nurses, consultants working with older people, pharmacists and inspectors. Copies may be purchased for $£ 5$ from Age Concern Mail Order Department, 1268 London Road, London SW16 4ER (cheques made payable to Age Concern England). Credit card orders can be made on 01717657203.
A new report investigating the risks to health and well-being from carbon monoxide exposure in the home has been published by the Institute for Environment and Health (IEH) at Leicester University. The IEH Assessment on Indoor Air Quality In The Home (2): Carbon Monoxide reviews information on the range of likely exposures to carbon monoxide in UK homes, and the possible health effects of these exposures. The report can be purchased from IEH, 94 Regent Road, Leicester LE1 7DD, price £25. For further scientific and technical information contact Dr Paul Harrison on 0116223 1610. For an executive summary (available to editors) contact the Scientific Publications and Information Unit on 01162231618 .

Ethnicity: An Agenda for Mental Health, edited by Dinesh Bhugra, sets the scene for identifying and meeting the mental health needs of Black and minority ethnic groups. In addition to multidisciplinary working, the key emphasis here is in involving commissioners and voluntary organisations in deciding how best to meet the needs of the communities. Copies will be available for $£ 15$ from Book Sales, The Royal College of Psychiatrists, 17 Belgrave Square, London SW1X 8PG (Telephone: 01712352351 ext. 146).

Seminars in Old Age Psychiatry is a new addition to the College seminar series. Edited by Rob Butler and Brice Pitt, it provides an impressive and comprehensive review of the diagnosis and management of psychiatric problems associated with old age. All the major disorders and approaches to treatment are covered. An essential text for trainees and clinicians. Copies are available for $£ 17.50$ from Book Sales, The Royal College of Psychiatrists, 17 Belgrave Square, London SW1X 8PG (Telephone: 0171 2352351 ext. 146).

Reciprocity Between the Royal College of Psychiatrists and the Royal Australian and New Zealand College of Psychiatrists Revised Statement (Council Report CR66) has recently been published. Although the nature and duration of training programmes and the timing and content of professional examinations differ between the two Colleges, each recognises broad equivalence and grants due recognition for such. The two tables of this document set out in detail reciprocal recognition of training and assessment, and also any exemptions allowed by the two Colleges. This statement replaces the earlier 
version published as CR45. Copies are available for $£ 5$ from Book Sales. The Royal College of Psychiatrists, 17 Belgrave Square, London SW1X 8PG (Telephone: 01712352351 ext. 146).

Working With People Who Self-Injure: A Modular Training Pack, developed and written by Lois Arnold for Bristol Crisis Service for Women, is designed for use in one- or two-day workshops in a variety of settings. All materials have been developed through Bristol Crisis Service for Women's extensive work with women who selfinjure, and training experience with a wide variety of agencies including mental health services, social services, secure settings and voluntary organisations. Booklets on Women and Self-Injury are also available. Packs or booklets may be obtained by sending a cheque or postal order, for $£ 70$ per pack or $£ 3$ per booklet, made payable to Bristol Crisis Service for Women at PO Box 654, Bristol BS99 1XH.

The Royal College of General Practitioners have recently published Genetics in Primary Care. A North West England Faculty of the CGP. Report from the Faculty Genetics Groups (Occasional paper OP77). This paper discusses the nature of genetic advances and presents an argument for genetic screening at a primary care level. Copies may be obtained from the RCGP Sales Office, 14 Princes Gate, Hyde Park, London SW7 1PU at a price of $£ 9$ for members and $£ 10$ for nonmembers. A 24-hour answerphone service for credit card orders is available on 01712253048.

The Policy Press have produced a number of publications under domestic violence and child welfare titles. These include Supporting Women and Challenging Men, Domestic Violence and Child Contact Arrangements in England and Denmark, and From Periphery to Centre:
Domestic Violence in Work With Abused Children. All publications cost $£ 11.95$ plus postage and package and may be obtained from Biblios Publishers' Distribution Services Ltd, Star Road, Partridge Green, West Sussex RH13 8LD. A customer credit card orderline is also available on 01403710851 .

Statutory Intervention in Child Protection Research Project: Thematic Summary by Joan Hung and Alison Macleod highlights the main findings of the full research project conducted for the Department of Health by the Centre for SocioLegal Studies at Bristol University. This project examines the impact of the Children Act on the use of compulsory measures of intervention in troubled families and addresses whether the legal framework introduced by the Act is workable and appropriate. Conference Report: Cleveland Ten Years On-Child Protection-What Really Matters? contains a compilation of the presentations given at this conference. Both the summary and report may be obtained from The National Council for Family Proceedings, University of Bristol, Rodney Lodge, Grange Road. Clifton, Bristol BS8 4EA, price $£ 7.50$ and $£ 10$ respectively.

The UK Alcohol Forum has produced a booklet entitled Guidelines for the Management of Alcohol Dependence in Primary Care and General Psychiatry. It is intended to meet the needs of general practitioners and psychiatrists who do not specialise in treating alcohol-related problems, but are nevertheless seeing many such patients. Free copies are available from the UK Alcohol Forum, 2 Newmans Row, Lincolns Inn, Lincoln Road, High Wycombe, Bucks HP12 3RE. 